\title{
LGM and Late Glacial glacier advances in the Cordillera Real and Cochabamba (Bolivia) deduced from ${ }^{10}$ Be surface exposure dating
}

\author{
R. Zech ${ }^{1}$, Ch. Kull ${ }^{2}$, P. W. Kubik ${ }^{3}$, and H. Veit ${ }^{1}$ \\ ${ }^{1}$ Geographical Institute, University of Bern, Switzerland \\ ${ }^{2}$ OcCC, Schwarztorstr. 9, 3007 Bern, Switzerland \\ ${ }^{3}$ Paul Scherrer Institute c/o Institute of Particle Physics, ETH Zurich, Switzerland
}

Received: 30 May 2007 - Published in Clim. Past Discuss.: 27 June 2007

Revised: 12 October 2007 - Accepted: 16 October 2007 - Published: 26 October 2007

\begin{abstract}
Surface exposure dating (SED) is an innovative tool already being widely applied for moraine dating and for Late Quaternary glacier and climate reconstruction. Here we present exposure ages of 28 boulders from the Cordillera Real and the Cordillera Cochabamba, Bolivia. Our results indicate that the local Last Glacial Maximum (LGM) in the Eastern Cordilleras occurred at $\sim 22-25 \mathrm{ka}$ and was thus synchronous to the global temperature minimum. We were also able to date several Late Glacial moraines to $\sim 11-13 \mathrm{ka}$, which likely document lower temperatures and increased precipitation ("Coipasa" humid phase). Additionally, we recognize the existence of older Late Glacial moraines recalculated to $\sim 15 \mathrm{ka}$ from published cosmogenic nuclide data. Those may coincide with the cold Heinrich 1 event in the North Atlantic region and the pronounced "Tauca" humid phase. We conclude that (i) exposure ages in the tropical Andes may have been overestimated so far due to methodological uncertainties, and (ii) although precipitation plays an important role for glacier mass balances in the tropical Andes, it becomes the dominant forcing for glaciation only in the drier and thus more precipitation-sensitive regions farther west and south.
\end{abstract}

\section{Introduction}

Reconstruction of past climatic conditions is important to identify relevant forcings and mechanisms of climate change. Long high-resolution records are available at high latitudes (ice-cores from Greenland and Antarctica) and from marine sediments. Comparable tropical and subtropical terrestrial records, however, are more scarce. Here, glacial deposits may provide valuable information about temperature and precipitation changes, the two dominant controls on glacier

Correspondence to: R. Zech

(roland.zech@giub.unibe.ch) extent (Kaser, 2001; Kull et al., 2003, 2007). So far, the lack of organic material for radiocarbon dating has been a major limiting factor for the establishment of reliable glacial chronologies, especially in dry mountain regions, such as the Central Andes (15-35 S) (Harrison, 2004; Heine, 2004; Mark et al., 2004). Surface exposure dating (SED) with cosmogenic radionuclides (CRN) is an innovative new method that may provide the means to date glacial deposits more accurately (Gosse and Phillips, 2001).

The Central Andes are part of the PEP I transect (Markgraf et al., 2000, Pole-Equator-Pole American Transect: http: //www.pages.unibe.ch) and are a key area for global climate reconstruction because they lie at the transition zone between the mid-latitude and the tropical atmospheric circulation (the westerlies in the south: Vuille and Ammann, 1997; and the South American Summer Monsoon (SASM) in the north: Zhou and Lau, 1998; Vuille and Keimig, 2004; see also Fig. 1). Intensity changes and shifts of the two circulation systems should therefore be recorded in suitable archives, including glacial chronologies. Extensive SED was recently conducted in the Eastern Cordillera of Bolivia and Peru by Smith et al. (2005a, b). They concluded that glaciers reached their greatest extent at $\sim 34 \mathrm{ka}$ and were retreating by $\sim 21 \mathrm{ka}$. This would imply that tropical controls on ice volumes were asynchronous with those in the northern hemisphere, which would have far-reaching consequences concerning the interhemispheric linkages. It has already been speculated that the Andean tropics and the mid-latitude southern hemisphere may lead the polar regions (Shulmeister et al., 2006). On the other hand, Schaefer et al. (2006) referred to the Late Glacial moraines from this very dataset of Smith et al. as corroborating evidence for a near-synchronous interhemispheric termination of the LGM (Last Glacial Maximum) in mid-latitudes after ca. $17-18 \mathrm{ka}$.

With this study, we hope to further illustrate the high potential of SED, while increasing awareness of the method's current limitations. We

Published by Copernicus Publications on behalf of the European Geosciences Union. 


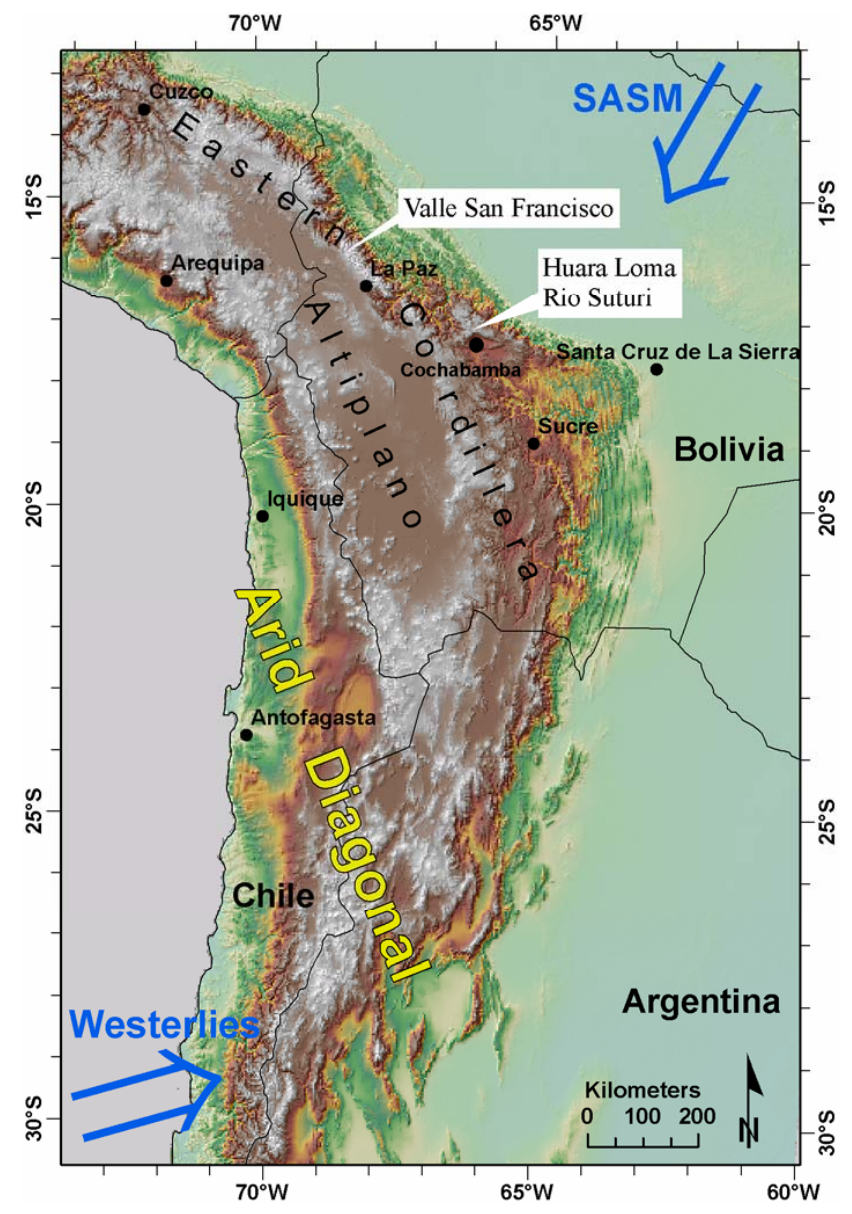

Fig. 1. Location of the research areas. The Valle San Francisco (Cordillera Real) and the Valle de Rio Suturi and Huara Loma (Cordillera Cochabamba) are situated at the north-eastern transition zone from the Altiplano to the lowlands of Bolivia and the Amazon Basin. SASM = South American Summer Monsoon.

(i) present results of our ${ }^{10} \mathrm{Be}$ (beryllium) $\mathrm{SED}$ in the Cordillera Cochabamba and the Cordillera Real, Bolivia;

(ii) derive a "relative" glacial chronology addressing potential causes for the observed scatter in ages;

(iii) highlight the systematic uncertainties of the exposure ages; and

(iv) discuss the paleoclimatic context and the possible implications of our results.

\section{Regional setting}

The Cordillera Cochabamba and the Cordillera Real form the north-eastern boundary of the Altiplano plateau $(\sim 3800 \mathrm{~m})$ towards the Amazon Basin (Fig. 1). Some summits reach altitudes of more than $6000 \mathrm{~m}$. The steep altitude gradient causes a pronounced climatic gradient. Precipitation decreases from $>1500 \mathrm{~mm} / \mathrm{a}$ in the lowlands to the east and northeast to $\sim 1000 \mathrm{~mm} / \mathrm{a}$ in the Cordilleras and to less than $500 \mathrm{~mm} / \mathrm{a}$ on the Altiplano. Further south, where the so-called "Arid Diagonal" crosses the Central Andes (25$27^{\circ} \mathrm{S}$ ), no glaciers exist even at altitudes above $6000 \mathrm{~m}$ (Ammann et al., 2001; Kull et al., 2002).

Large moraines in the Eastern Cordillera document Late Quaternary periods much more favourable for glaciation than today, that is with lower temperatures and/or increased precipitation. However, considerable uncertainties concerning the glacial chronology exist. Based on soil development on moraines, bedded slope deposits and basal radiocarbon ages, various authors have suggested a local LGM either before, synchronous or after the global LGM (recently reviewed by Heine, 2004; Mark et al., 2004; and Smith et al., $2005 \mathrm{c}$ ). In addition, there is no consensus concerning the existence and/or the exact timing of Late Glacial readvances such as the Younger Dryas (YD) or the Antarctic Cold Reversal (ACR). The aforementioned reviews of the region's glacial history all highlight the need for improved age control.

In order to provide some dating control on the glacial chronology in the Eastern Cordillera, we selected three research areas for ${ }^{10} \mathrm{Be}$ SED based on the occurrence of welldefined moraine stratigraphy and the availability of suitable (i.e. large and quartz-bearing) boulders (Fig. 1):

- Valle San Francisco (south-western side of the Illampu massif, $\left.16.00^{\circ} \mathrm{S}, 68.54^{\circ} \mathrm{W}\right), \sim 80 \mathrm{~km}$ northwest of $\mathrm{La}$ Paz

- Valle de Rio Suturi $\left(17.23^{\circ} \mathrm{S}, 66.45^{\circ} \mathrm{W}\right), \sim 30 \mathrm{~km}$ northwest of Cochabamba

- Valle Huara Loma $\left(17.21^{\circ} \mathrm{S}, 66.26^{\circ} \mathrm{W}\right), \sim 15 \mathrm{~km}$ north of Cochabamba

\section{Materials and methods}

Fieldwork included mapping of the moraines, sampling of suitable boulders $(\sim 0.5 \mathrm{~kg}$ from the flat top of preferentially large, stable and uneroded boulders), and documentation of the samples (geographic location (GPS), topographic shielding, sample geometry, and photographs: see supplementary material A.1 (http://www.clim-past.net/ 3/623/2007/cp-3-623-2007-supplement.pdf) for the sample photos). Laboratory preparation and analysis followed standard procedures (e.g. Ivy-Ochs, 1996). In brief, this involved (i) separation of quartz, (ii) dissolution of the quartz in HF after addition of ${ }^{9} \mathrm{Be}$ carrier, (iii) chromatographical purification of beryllium (Be), (iv) precipitation and oxidation, and (v) AMS measurement of the ${ }^{10} \mathrm{Be}$ over ${ }^{9} \mathrm{Be}$ ratio. 
Surface exposure dating is based on the production and accumulation of cosmogenic nuclides (e.g. $\left.{ }^{10} \mathrm{Be}\right)$ in the upper few decimetres of an exposed rock surface (Gosse and Phillips, 2001). In order to calculate the exposure age of a sample from its ${ }^{10} \mathrm{Be}$ concentration, the local ${ }^{10} \mathrm{Be}$ production rate must be estimated. This is accomplished by scaling a reference production rate (typically at sea level and high latitude, SLHL) to the sampling location, using scaling models that describe the latitude and altitude dependence of the cosmic radiation. Several scaling models have been proposed (Lal, 1991; Dunai, 2000, 2001; Stone, 2000; Desilets and Zreda, 2001, 2003; Lifton et al., 2005; Desilets et al., 2006), but currently there is debate as to which is most appropriate. Uncertainties in the predictions of these various models are variable, but are typically quoted as being on the order of $10-15 \%$ (Gosse and Phillips, 2001). Major international efforts currently are aimed at the development of an internationally accepted protocol to calculate exposure ages with accuracy of at least 5\% (CRONUS-Earth and CRONUS-EU projects: www.physics.purdue.edu/cronus and http://www. cronus-eu.net, respectively). Therefore, while we calculated the exposure ages below using the scaling model of Lifton et al. (2005), we also examined the sensitivity of our calculated exposure ages to various calculations schemes and assumptions. All presented ages are corrected for topographic shielding (Dunne et al., 1999) and sample thickness, whereas snow and vegetation cover can likely be neglected due to the relatively dry conditions and the scarce vegetation cover.

\section{Results and discussion}

Exposure ages and the relevant sample data are given in Table 1 . We will first present the exposure ages in their stratigraphic context (Figs. 2-4). Then, we will address the age scatter due to sample-specific effects, that is possible overor underestimation of the deposition age of the respective moraine (all ages plotted in Fig. 5). Subsequently, we will discuss the systematic uncertainties (Fig. 6). Finally, the paleoclimatic context and the paleoclimatic implications of our results will be addressed.

4.1 Stratigraphy and exposure ages in the Valle San Francisco, Rio Suturi and Huara Loma

Our stratigraphic field work in the Valle San Francisco corroborates previous detailed work by Jordan et al. (1993). A large number of (recessional) stages is documented by numerous lateral and terminal moraines. Only the major stages could be sampled, however, due to the need for large boulders, which were not present on moraines associated with minor stages (see Fig. 2 for the sampling locations). The oldest dated glacial deposit is an outer lateral moraine at $\sim 4670 \mathrm{~m}$ altitude, where three boulders yielded exposure ages of $18.5 \pm 0.8,22.6 \pm 0.8$ and $24.1 \pm 0.9 \mathrm{ka}$ (samples SF41-
$3)$. The dominant inner lateral moraine yields boulder ages of $17.2 \pm 0.7$ and $19.3 \pm 0.6 \mathrm{ka}$ (SF32 and 33) and probably correlates with a lateral moraine on the other side of the valley, where two boulders date to $15.3 \pm 0.7$ and $20.3 \pm 0.8 \mathrm{ka}$ (SF12 and 13). Three boulders from a recessional end moraine in the valley bottom yield exposure ages of $9.4 \pm 0.6,12.9 \pm 0.6$ and $11.5 \pm 0.5 \mathrm{ka}$ (SF51-3), and the youngest dated end terminal moraine, which dams the Laguna San Francisco, yielded boulder ages of $10.4 \pm 0.5$ and $10.0 \pm 0.5 \mathrm{ka}$ (SF21 and 22).

In the Valle de Rio Suturi, two boulders from the prominent latero-frontal moraine date to $13.0 \pm 0.8$ and $11.6 \pm 0.6 \mathrm{ka}$ (RM31 and 33, see Fig. 3). A boulder from an adjacent, stratigraphically older lateral moraine remnant has an exposure age of $10.1 \pm 0.8 \mathrm{ka}$ (RM22). The oldest age in the Valle de Rio Suturi was obtained from the remnants of a middle moraine preserved between Valle de Rio Suturi and the northern neighbouring valley: boulder RM41 has an exposure age of $22.0 \pm 1.2 \mathrm{ka}$. Another boulder (RM42) from that location is $12.2 \pm 0.9 \mathrm{ka}$ old. The most prominent of a number of recessional moraines was sampled as well. Boulder ages there are $12.2 \pm 0.7$ and $10.3 \pm 0.7 \mathrm{ka}$ (RM13 and 14). The youngest age was obtained from a terminal moraine upvalley (boulder RM51: 7.0 $\pm 0.5 \mathrm{ka}$ ).

The stratigraphic situation in the Valle Huara Loma may be more complicated than initially thought (Fig. 4). The oldest exposure ages that we obtained are from boulders on an outer lateral moraine $(16.9 \pm 0.6$ and $14.6 \pm 0.5 \mathrm{ka}, \mathrm{HH} 51$ and $52)$. Just inside, another lateral moraine yields two boulder ages of $11.8 \pm 0.5$ and $11.4 \pm 0.5 \mathrm{ka}$ (HH41 and HH43). Up-valley, boulders on the large prominent lateral moraine yield exposure ages of $13.3 \pm 0.6$ and $11.5 \pm 0.4 \mathrm{ka}$ (HH11 and 22). Two boulders from a recessional moraine are dated to $10.4 \pm 0.5$ and $11.0 \pm 0.4 \mathrm{ka}$ (HH31 and 32).

\subsection{Exposure age scatter: inheritance versus degradation}

Interpretation of exposure ages is principally limited by two possible sources of errors: "Inheritance" and "degradation". Inherited nuclide concentration due to exposure before moraine deposition can lead to an overestimation of the deposition age. Although it is difficult to determine whether and to what extent a boulder was "pre-exposed", probability for inheritance is generally assumed to be very low (Shanahan and Zreda, 2000; Putkonen and Swanson, 2003). On the other hand, exposure ages may underestimate the deposition age, when formerly covered boulders were exposed after deposition, for example due to denudation of the moraine matrix, frost-induced upheaval, toppling of boulders, melting of buried glacier ice (Briner et al., 2005; Zech et al., 2005; Putkonen and O'neal, 2006). Furthermore, rock surface erosion has the same effect, as it results in loss of accumulated cosmogenic nuclides. The "oldest age model" suggests that, generally, the oldest exposure age from a landform feature yields the closest approximation of the deposition age. The oldest age may possibly still be too young. It should be 
Table 1. Sample data and exposure ages calculated according to Lifton et al. (2005), Pigati and Lifton (2004) (“P \& L") and Stone (2000). Reference production rates are 5.87, 5.41 and 5.1 atoms $\mathrm{a}^{-1} \mathrm{~g}^{-1} \mathrm{SiO}_{2}$, respectively, calculated from the calibrations sites used by Stone (2000).

\begin{tabular}{|c|c|c|c|c|c|c|c|c|c|}
\hline Sample & $\begin{array}{l}\text { Latitude } \\
{ }^{\circ} \mathrm{S}\end{array}$ & $\begin{array}{l}\text { Longitude } \\
{ }^{\circ} \mathrm{W}\end{array}$ & $\begin{array}{l}\text { Altitude } \\
\text { [m a.s.l.] }\end{array}$ & $\begin{array}{r}{ }^{10} \mathrm{Be} \\
{\left[10^{5} \text { at } / \mathrm{g} \mathrm{SiO}_{2}\right]}\end{array}$ & AMS SD & $\begin{array}{l}\text { Topographic } \\
\text { Shielding } \\
\text { Factor }^{\mathrm{b}}\end{array}$ & $\begin{array}{l}\text { Exposure } \\
\text { Ages }^{\mathrm{c}} \\
\text { Lifton }[\mathrm{ka}]\end{array}$ & $\begin{array}{l}\text { Exposure } \\
\text { Ages }^{\mathrm{c}} \\
\text { P \& L }\end{array}$ & $\begin{array}{c}\text { Exposure } \\
\text { Ages }^{\mathrm{c}} \\
\text { Stone }\end{array}$ \\
\hline \multicolumn{10}{|c|}{ Valle San Francisco: } \\
\hline SF12 & 15.97 & 68.53 & 4752 & 10.78 & 4.3 & 1 & $\mathbf{1 5 . 3} \pm 0.7$ & $15.1 \pm 0.6$ & $18.2 \pm 0.8$ \\
\hline SF13 & 15.97 & 68.53 & 4750 & 15.19 & 3.9 & 1 & $\mathbf{2 0 . 3} \pm 0.8$ & $20.1 \pm 0.8$ & $25.7 \pm 1.0$ \\
\hline SF21 & 15.94 & 68.53 & 4600 & 6.32 & 4.5 & 0.98 & $\mathbf{1 0 . 4} \pm 0.5$ & $10.2 \pm 0.5$ & $11.6 \pm 0.5$ \\
\hline $\mathrm{SF} 23$ & 15.94 & 68.53 & 4601 & 6.02 & 4.5 & 0.98 & $\mathbf{1 0 . 0} \pm 0.5$ & $9.8 \pm 0.4$ & $11.0 \pm 0.5$ \\
\hline SF32 & 15.97 & 68.55 & 4690 & 12.05 & 4.0 & 1 & $\mathbf{1 7 . 2} \pm 0.7$ & $16.9 \pm 0.7$ & $20.9 \pm 0.8$ \\
\hline SF33 & 15.98 & 68.55 & 4691 & 13.85 & 3.2 & 1 & $\mathbf{1 9 . 3} \pm 0.6$ & $19.1 \pm 0.6$ & $24.0 \pm 0.8$ \\
\hline SF41 & 15.98 & 68.54 & 4665 & 12.95 & 4.4 & 1 & $\mathbf{1 8 . 5} \pm 0.8$ & $18.2 \pm 0.8$ & $22.7 \pm 1.0$ \\
\hline SF42 & 15.98 & 68.54 & 4666 & 16.42 & 3.5 & 1 & $\mathbf{2 2 . 6} \pm 0.8$ & $22.3 \pm 0.8$ & $28.8 \pm 1.0$ \\
\hline SF43 & 15.98 & 68.54 & 4667 & 17.87 & 3.5 & 1 & $\mathbf{2 4 . 1} \pm 0.9$ & $23.8 \pm 0.8$ & $31.3 \pm 1.1$ \\
\hline SF51 & 16.00 & 68.54 & 4470 & 5.40 & 6.1 & 1 & $\mathbf{9 . 4} \pm 0.6$ & $9.2 \pm 0.6$ & $10.3 \pm 0.6$ \\
\hline SF52 & 16.00 & 68.54 & 4471 & 7.64 & 4.3 & 1 & $\mathbf{1 2 . 9} \pm 0.6$ & $12.6 \pm 0.5$ & $14.6 \pm 0.6$ \\
\hline SF53 & 16.00 & 68.54 & 4472 & 6.80 & 4.0 & 1 & $\mathbf{1 1 . 5} \pm 0.5$ & $11.3 \pm 0.5$ & $13.0 \pm 0.5$ \\
\hline \multicolumn{10}{|c|}{ Valle de Rio Suturi: } \\
\hline RM13 & 17.23 & 66.44 & 3930 & 5.33 & 5.8 & 0.97 & $\mathbf{1 2 . 2} \pm 0.7$ & $12.0 \pm 0.7$ & $13.3 \pm 0.8$ \\
\hline RM14 & 17.23 & 66.44 & 3931 & 4.40 & 6.8 & 0.97 & $\mathbf{1 0 . 3} \pm 0.7$ & $10.1 \pm 0.7$ & $10.9 \pm 0.7$ \\
\hline RM22 & 17.23 & 66.46 & 3801 & 4.02 & 7.6 & 0.97 & $\mathbf{1 0 . 1} \pm 0.8$ & $9.9 \pm 0.7$ & $10.7 \pm 0.8$ \\
\hline RM31 & 17.23 & 66.46 & 3780 & 5.24 & 5.9 & 0.97 & $\mathbf{1 3 . 0} \pm 0.8$ & $12.8 \pm 0.8$ & $14.0 \pm 0.8$ \\
\hline RM33 & 17.23 & 66.46 & 3780 & 4.61 & 5.2 & 0.97 & $\mathbf{1 1 . 6} \pm 0.6$ & $11.4 \pm 0.6$ & $12.3 \pm 0.6$ \\
\hline RM41 & 17.22 & 66.47 & 3863 & 10.30 & 5.6 & 0.98 & $\mathbf{2 2 . 0} \pm 1.2$ & $21.9 \pm 1.2$ & $26.3 \pm 1.5$ \\
\hline RM42 & 17.22 & 66.47 & 3868 & 5.23 & 7.0 & 0.98 & $\mathbf{1 2 . 2} \pm 0.9$ & $12.0 \pm 0.8$ & $13.3 \pm 0.9$ \\
\hline RM51 & 17.22 & 66.41 & 4344 & 3.59 & 7.6 & 0.97 & $\mathbf{7 . 0} \pm 0.5$ & $6.9 \pm 0.5$ & $7.3 \pm 0.6$ \\
\hline \multicolumn{10}{|c|}{ Valle Huara Loma: } \\
\hline HH11 & 17.22 & 66.26 & 4380 & 7.74 & 4.7 & 1 & $\mathbf{1 3 . 3} \pm 0.6$ & $13.1 \pm 0.6$ & $15.1 \pm 0.7$ \\
\hline HH22 & 17.21 & 66.26 & 4360 & 6.56 & 3.7 & 1 & $\mathbf{1 1 . 5} \pm 0.4$ & $11.4 \pm 0.4$ & $12.9 \pm 0.5$ \\
\hline HH31 & 17.21 & 66.27 & 4212 & 5.25 & 4.9 & 0.98 & $\mathbf{1 0 . 4} \pm 0.5$ & $10.2 \pm 0.5$ & $11.3 \pm 0.5$ \\
\hline HH32 & 17.21 & 66.27 & 4213 & 5.61 & 3.8 & 0.98 & $\mathbf{1 1 . 0} \pm 0.4$ & $10.8 \pm 0.4$ & $12.1 \pm 0.5$ \\
\hline HH41 & 17.20 & 66.26 & 4225 & 6.20 & 4.6 & 1 & $\mathbf{1 1 . 8} \pm 0.5$ & $11.5 \pm 0.5$ & $13.0 \pm 0.6$ \\
\hline HH43 & 17.20 & 66.26 & 4225 & 6.04 & 4.4 & 1 & $\mathbf{1 1 . 4} \pm 0.5$ & $11.3 \pm 0.5$ & $12.6 \pm 0.6$ \\
\hline HH51 & 17.21 & 66.26 & 4222 & 9.41 & 3.6 & 1 & $\mathbf{1 6 . 9} \pm 0.6$ & $16.7 \pm 0.6$ & $19.8 \pm 0.7$ \\
\hline HH52 & 17.21 & 66.26 & 4223 & 7.93 & 3.5 & 1 & $\mathbf{1 4 . 6} \pm 0.5$ & $14.4 \pm 0.5$ & $16.7 \pm 0.6$ \\
\hline
\end{tabular}

a $\mathrm{AMS} \mathrm{SD}=1 \sigma$ standard deviation of the AMS measurement

$\mathrm{b}$ all ages are additionally corrected with a sample thickness factor of $0.97(\sim 3-4 \mathrm{~cm})$

${ }^{\mathrm{c}}$ with the propagated $1 \sigma$ standard deviation of the AMS measurement

rejected as too old (due to inheritance) only if that seems very likely based on the age distribution of a large dataset or based on the stratigraphic context.

In order to illustrate the scatter in our data and to identify possible outliers, we plot all exposure ages in stratigraphic order (Fig. 5). Our data set is admittedly too limited to identify with certainty all boulders that may have problems with prior exposure. Applying the "oldest age model" allows us to establish the following tentative chronology. In the Valle San Francisco the outer lateral moraine documents a glacial advance at $\sim 24.1 \pm 0.9 \mathrm{ka}$ (SF43). The subsequent prominent glacial advance is dated to $\sim 20.3 \pm 0.8 \mathrm{ka}$ (SF13), and the recessional stages also yield stratigraphically consistent ages of $12.9 \pm 0.6$ (SF52) and $10.4 \pm 0.5 \mathrm{ka}$ (SF21), respectively. The age of the oldest deposit in the Valle de Rio Suturi clearly requires verification; it may be as old as $22.0 \pm 1.2 \mathrm{ka}$ (RM41), but this conclusion is based only on a single age. The prominent latero-frontal moraine is more confidently dated to $\sim 13.0 \pm 0.8 \mathrm{ka}$ (RM31), although a younger exposure age of $10.1 \pm 0.8 \mathrm{ka}$ (RM22) is obtained from the adjacent, stratigraphically older moraine remnant. The assumption that this 10.1 age is a "degradation" age is corroborated by the recessional moraine up-valley dated to $\sim 12.2 \pm 0.7 \mathrm{ka}$ (RM13). Finally, a much younger age (7.0 $\pm 0.5 \mathrm{ka}, \mathrm{RM} 51)$ 


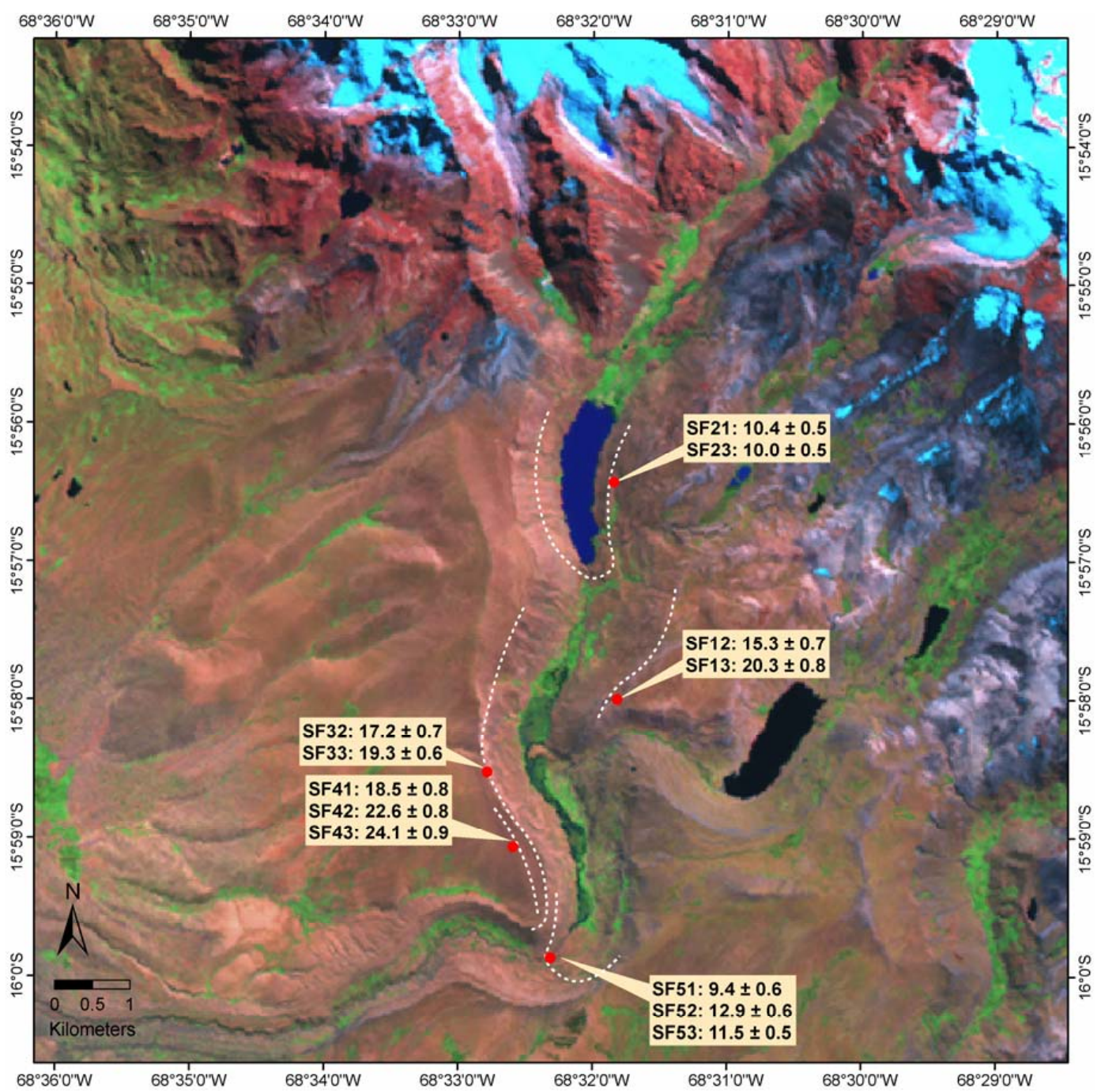

Fig. 2. Landsat image (RGB 742) showing the geomorphological and stratigraphical situation in the Valle San Francisco. Sampling locations and exposure ages in ka (calculated according to Lifton et al., 2005, and a reference production rate of $5.87 \mathrm{atoms} \mathrm{a}^{-1} \mathrm{~g}^{-1} \mathrm{SiO}_{2}$ ) are indicated. The dotted lines illustrate the unambiguous extent of the sampled moraines.

is obtained from another recessional stage, but it awaits corroboration. In the Valle Huara Loma, a minimum age of $16.9 \pm 0.6 \mathrm{ka}$ (HH51) characterizes the outer lateral moraine. We can only speculate about its correlation with the older moraines in the other two valleys, since both boulders clearly had signs of erosion and are not perfectly suited for SED (see photos in the supplementary material). The inner lateral moraine yields an age of $11.8 \pm 0.5 \mathrm{ka}$ (HH41). This seems to contradict the minimum age inferred for the upper lateral moraine, which is tentatively dated to $13.3 \pm 0.6 \mathrm{ka}$ (HH11). We note, however, that the complicated stratigraphic situation does not rule out that the lower, inner lateral moraine actually documents a glacial advance inside the older, high lateral moraine. Finally, the innermost recessional moraine is dated to $11.0 \pm 0.4 \mathrm{ka}$ (HH32).
The above discussion shows that interpreting our dataset using the "oldest age model" leads to a generally consistent picture of glaciation: The oldest deposits are roughly dated to $22-25 \mathrm{ka}$ ( $>17 \mathrm{ka}$ in the Valle Huara Loma), and substantial readvances - especially in the Cordillera Cochabamba - occurred between $\sim 11-13 \mathrm{ka}$. Undoubtedly, more exposure ages would help to corroborate and refine the glacial chronologies in the research areas.

\subsection{Systematic uncertainties of the exposure ages}

Interpretation of exposure age chronologies in the paleoclimatic context requires awareness of the systematic uncertainties. These are uncertainties due to scaling and the reference production rate. As already mentioned, there is currently no internationally accepted way to calculate exposure ages. 


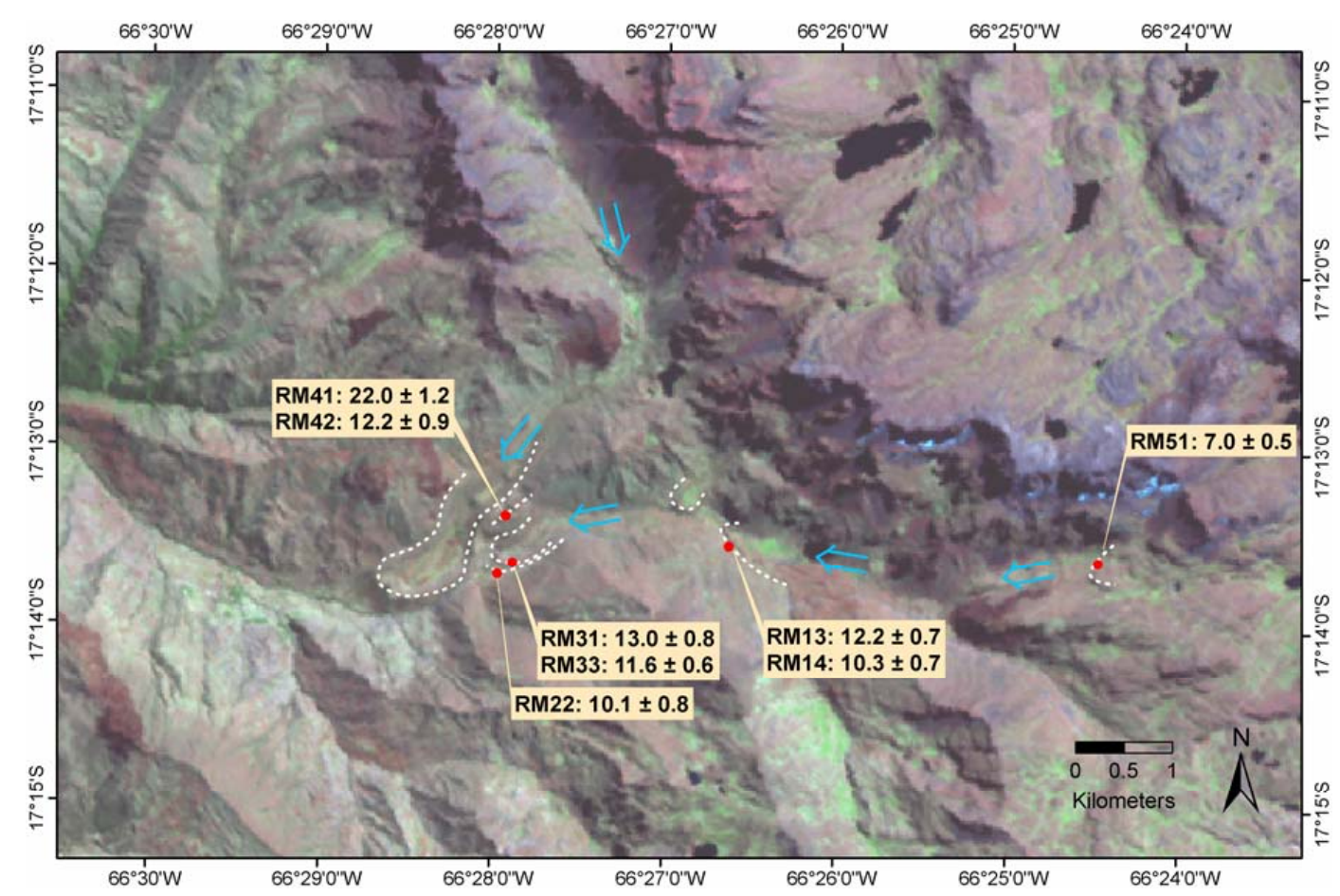

Fig. 3. Same as Fig. 2 for the Valle de Rio Suturi. The arrows show the former ice-flow direction.

The exposure ages presented above have been calculated according to Lifton et al. (2005). Their model takes into account past changes of the geomagnetic field intensity (composite model based on Guyodo and Valet, 1999 (Sint800); and Yang et al., 2000), the dipole wobble for the Holocene (composite model based on Merrill and McElhinny, 1983; and Ohno and Hamano, 1993), and solar modulation (based on Solanki et al., 2004). Additionally, fast and slow muons are scaled independently of the neutron flux. We used a total reference production rate of 5.87 atoms a ${ }^{-1} \mathrm{~g}^{-1} \mathrm{SiO}_{2}$. This value has been derived from calibration of the cosmogenic nuclide data that were used by Stone (2000) to derive a production rate of 5.1 atoms a $\mathrm{a}^{-1} \mathrm{~g}^{-1} \mathrm{SiO}_{2}$. Respective data were accessed in May 2007 from the website of the "Cosmogenic Isotope Laboratory, University of Washington" (http://depts.washington.edu/cosmolab/). Note that significantly younger exposure ages are obtained when using the scaling system of Lifton et al. (2005) instead of Stone (2000) (open squares in Fig. 6). Due to its simplicity, the scaling system of Stone is still widely used, but major potential error sources are that (i) it is based on a relatively small neutron flux dataset, (ii) it neglects the altitude dependence of the energy spectrum of the cosmic radiation, and (iii) it does not take into account past changes of the geomagnetic field.

The 10\% error bars for the "Lifton ages" in Fig. 6 illustrate the estimated total systematic uncertainty of exposure dating according to Gosse and Phillips (2001). The 10\% figure in- cludes mainly uncertainties related to the reference production rate and to scaling. Given the uncertainty, the exposure ages calculated according to Pigati and Lifton (2004) (orange squares in Fig. 6) are in very good agreement with the "Lifton ages". Note that we up-dated the Pigati and Lifton spreadsheet, which is based on the scaling system of Desilets and Zreda (2003), with the new scaling coefficients published in Desilets et al. (2006). The reference production rate to use is $5.41 \mathrm{a}^{-1} \mathrm{~g}^{-1} \mathrm{SiO}_{2}$ - based on the same calibration sites as outlined above. Calculations according to Dunai (2001) are also in very good agreement, but results are not shown here because the application of that latter calculation scheme would ideally require local inclination data of the geomagnetic field.

Apart from the selection of the applied scaling system, three more factors contributing to the exposure age uncertainties shall briefly be discussed here: the use the Standard Atmosphere, neo-tectonics, and the eustatic sea level change.

(i) Altitude scaling requires the calculation of the atmospheric depth and the pressure, respectively, for the sampling locations. The application of the Standard Atmosphere, as used in the calculations above, is only a rough estimate for the real atmospheric conditions (Stone, 2000). Parameterisation of the pressure-altitude relationship in the Central Andes according to Farber et al. (2005: sea level pressure 1012.8 instead of $1013.15 \mathrm{mbar}$, and sea-level temperature 301.73 instead of $288.15 \mathrm{~K}$ ) would result in ages slightly older than the ones presented above (blue diamonds in Fig. 6). However, 


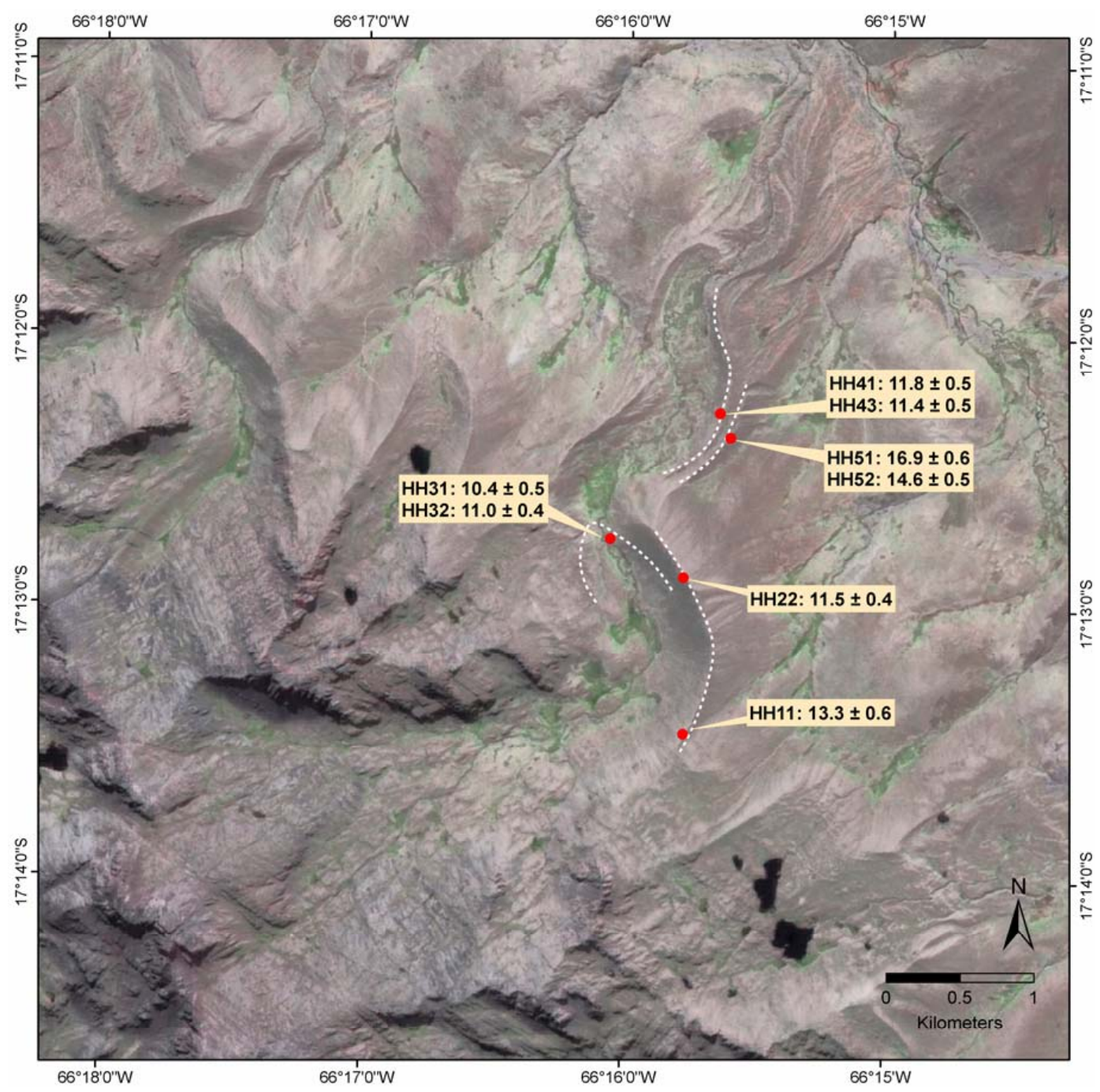

Fig. 4. Same as Fig. 2 for the Huara Loma (here a Corona image was draped over the Landsat data, RGB 742).

neither the temperature nor the lapse rate can be assumed to have been constant over time and reliable reconstructions of these parameters are not available.

(ii) Neo-tectonics would also affect altitude scaling. Whereas Holocene exposure ages would hardly change, an uplift rate of $5 \mathrm{~mm} / \mathrm{a}$ would already increase the calculated age of a " 20 ka-boulder" by $\sim 2.5 \%$ (i.e. $0.5 \mathrm{ka}$ ). Although the main Andean orogenesis is generally assumed to have ceased several million years ago and values for current uplift rates are thought to be an order of magnitude smaller than $5 \mathrm{~mm} / \mathrm{a}$ (Smith et al., 2005a), there is geomorphologic evidence for very active regions today (e.g. faulted moraines), so that exposure age errors due to neo-tectonics cannot be excluded.

(iii) Finally, the lowering of the eustatic sea level during the LGM (e.g. Fleming et al., 1998) increases the "apparent" altitude of the samples. A correction of $\sim 2.5 \%$ towards younger ages would, for example, seem to be necessary for a 20 ka-boulder. However, according to Osmaston (2006), air pressure and thus altitude scaling at a given location do not change because of replacement of air by the growing ice sheet masses during the LGM.

Summarizing, we emphasize that although we currently favour the application of the calculation scheme according to Lifton et al. (2005) as outlined above, there is an urgent need for local calibration studies in the Andes in order to better constrain the systematic uncertainties. This is not only important with regard to the scaling system, but also with regard to the reference production rate, which will be addressed below in more detail.

\subsection{Paleoclimatic context and implications}

In the following, we will first compare our results with the surface exposure age chronologies of Smith et al. (2005a, b) and Farber et al. (2005), then with independent age controls 


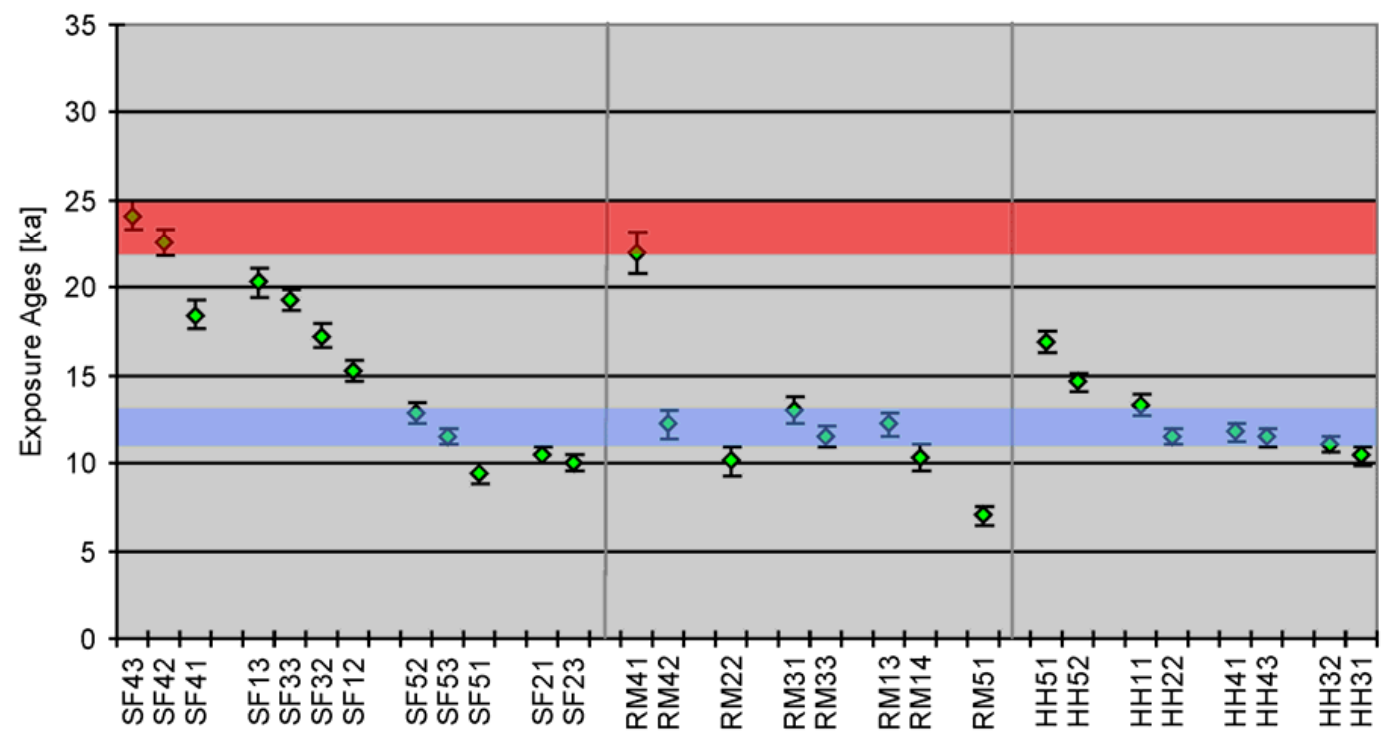

Fig. 5. Exposure ages from all three research areas arranged in stratigraphic order. Calculations according to Lifton et al. (2005) with a reference production rate of 5.87 atoms a $\mathrm{a}^{-1} \mathrm{giO}_{2}$. Errors bars illustrate the $1 \sigma$ AMS errors. The shaded red bar indicates the LGM glacial advances (22-25 ka), the blue bar the Late Glacial ones (11-13 ka).

on the glacial history in the research area. Thereafter, we will discuss the role of temperature and precipitation on the glaciation in the Central Andes.

\subsubsection{Comparison with published surface exposure ages}

Our exposure age dataset from Bolivia is admittedly small. In order to derive meaningful paleoclimatic interpretations we can, however, refer to the large dataset of Smith et al. (2005a, b) and Farber et al. (2005). Based on more than $100{ }^{10} \mathrm{Be}$ surface exposure ages, Smith et al. (2005a) suggested that glaciers reached their greatest extent at $\sim 32 \mathrm{ka}$ and were retreating by $\sim 21 \mathrm{ka}$ (ages published in Smith et al., 2005a, are slightly younger than the ones published in Smith et al., $2005 \mathrm{~b}$, because a revised geomagnetic correction was used in the calculations, see Fig. 7). Farber et al. (2005) dated glacial advances to $\sim 29$ and $16.5 \mathrm{ka}$ (geomagnetically corrected), respectively. These results seem to disagree with our chronology (glacial advances at $\sim 22-25$ and 11-13 ka), but re-calculation of the exposure ages of Smith et al. and Farber et al. using Lifton et al. (2005) instead of Stone (2000) yields considerably lower ages. Figure 7 illustrates this for the samples from Valle Antacocha in Peru. The recalculated exposure ages are in much better agreement with our results, indicating that the maximum glaciation during the last glacial cycle occurred at $\sim 22-25 \mathrm{ka}$ (presuming that Lifton et al., 2005, is the correct scaling method). Maximum glaciation may thus have occurred later than previously assumed and roughly synchronous with the global temperature minimum. A recessional moraine in the Valle Antacocha is recalculated to $\sim 15 \mathrm{ka}$. This advance is clearly older than the Late Glacial advances that we dated. Younger Late Glacial moraines (re- calculated ages $\sim 12 \mathrm{ka}$ ) are described, however, for example in the Calcalcocha Valley (Smith et al., 2005a, b) or at the "Breque" site in Peru (also shown in Fig. 7) (Farber et al., 2005). Note that for illustration in Fig. 7 we intentionally chose moraines with a low scatter in ages only. Larger scatter indicates that the glacial morphologies may be more complicated or that dating those moraines is more challenging due to rock surface erosion or landscape instability.

The Breque moraine deserves further emphasis, because it may actually serve as a local calibration site, having been independently dated to $\sim 13.1$ cal. ka BP (Rodbell and Seltzer, 2000; Farber et al., 2005) (orange box in Fig. 7). Although the "Lifton ages" seem to be too young, we argue that his scaling system is nevertheless preferable over the one of Stone (2000) based on the reasons outlined above. Including atmospheric correction (blue diamonds in Fig. 7) increases the exposure ages, making them comparable to the previously published ones based on the scaling of Stone (2000), but still most boulders seems to be too young. Therefore and because the Breque site would yield a reference production rate of only 4.66 atoms a ${ }^{-1} \mathrm{~g}^{-1} \mathrm{SiO}_{2}$ compared to 5.87 atoms a ${ }^{-1} \mathrm{~g}^{-1} \mathrm{SiO}_{2}$ (mean of all other calibration sites), we currently doubt its correctness and we have not included the Breque site in the calculation of the mean reference production rate. Nevertheless, we cannot totally exclude the possibility that using Breque as local calibration site yields the best estimates for the real exposure ages in the tropical Andes. Corresponding results are therefore also shown in Fig. 6. The need for further research to reduce the exposure age uncertainties, particularly the need for more high-altitude calibration sites, is obvious. 


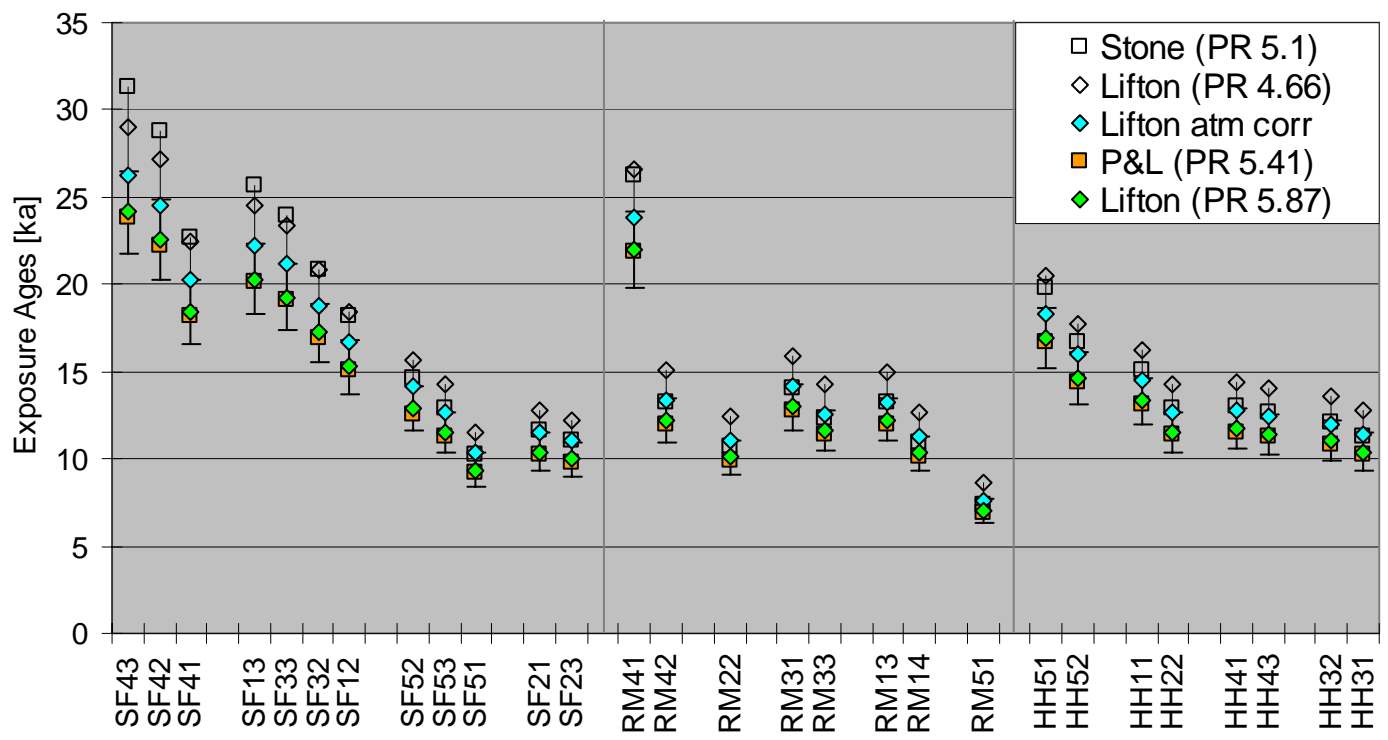

Fig. 6. Exposure ages calculated according to Lifton et al. (2005) with a reference production rate (PR) of 5.87, Pigati and Lifton (2004) PR 5.41, Stone (2000) PR 5.1, Lifton et al. (2005) including an estimated atmospheric correction, and Lifton et al. with a PR of 4.66 (Breque calibration site). Error bars: $10 \%$ for Lifton et al. (2005, PR 5.87).

\subsubsection{Independent age control}

There is not much independent dating control on the glacial advances in the Central Andes with which to evaluate our exposure age chronology. Most previous work is based on morphology, soil development and bedded slope deposits (e.g. Lauer and Rafiqpoor, 1986; Lauer and Rafiqpoor, 1989; Jordan et al., 1993; Reuter et al., 1995; Heine, 1996). Numerous minimum radiocarbon ages for moraines have been reported from basal peat and lake sediments (summarized in Smith et al., 2005c: minimum ages range from 9 to $12{ }^{14} \mathrm{C} \mathrm{kaBP}$, that is ca. 10 to $\left.14 \mathrm{cal} \mathrm{ka} \mathrm{BP}\right)$. In Peru, maximum-limiting ${ }^{14} \mathrm{C}$ ages suggest that substantial glacial stillstands or readvances there occurred between 16-13 cal ka BP (Rodbell, 1993; Seltzer et al., 1995; Rodbell and Seltzer, 2000). Although unfortunately poorly documented and highly uncertain (see Smith et al., 2005c), a maximum-limiting ${ }^{14} \mathrm{C}$ age in Bolivia is available for the Valle San Francisco ( $33{ }^{14} \mathrm{C}$ ka BP: Argollo, 1980) and bracketing ages exist for the Rio Kollpaña (Servant et al., 1981: 16.6 and $27{ }^{14} \mathrm{C} \mathrm{ka} \mathrm{BP}$, respectively). All these data are in agreement with our results of a maximum glaciation at $\sim 22-25 \mathrm{ka}$ and deglaciation after $\sim 11 \mathrm{ka}$.

There are, however, also findings that have been interpreted to corroborate an early local LGM: First, a minimum age for a glacial advance of $\sim 20{ }^{14} \mathrm{C} \mathrm{ka} \mathrm{BP}$ has been reported from the Laguna Kollpa Khota (Seltzer, 1994). We argue that this age $(\sim 24$ cal ka BP) does not necessarily contradict our proposed chronology, because it is just a minimum age for a potentially much older, and more extensive glaciation than the last one. Secondly, the sudden drops of magnetic sus- ceptibility (MS, a proxy for glacial flour) in the sediments of Lake Titicaca and Lake Junin at $\sim 20 \mathrm{ka} \mathrm{BP}$ have led Seltzer et al. (2002) to conclude that deglaciation occurred much earlier than in the Northern Hemisphere. However, glacial flour may be trapped very effectively as soon as the most extensive glacial stage is abandoned and a sediment trap is created behind the terminal moraines. Subsequent, although still significant, glacier fluctuations may therefore not be recorded in the MS signal. In fact, the MS signal in core NE985PC in Lake Titicaca (close to the Cordillera Real) reaches very high values just between 25 and $20 \mathrm{ka} \mathrm{BP}$ (Seltzer et al., 2002), indicating that the glaciers there (e.g. in the Valle San Francisco) were at their maximum at that time and not before. Our chronology is also in good agreement with a maximum ${ }^{14} \mathrm{C}$ age of $24.4 \mathrm{ka} \mathrm{BP}(\sim 27.4 \mathrm{cal} \mathrm{ka} \mathrm{BP})$ obtained from a soil intercalated between two moraines in the Cordillera Tunari near Cochabamba (J.-H. May, 2007, personal communication). The last glacial ice advance thus did not reach that site before that time. The basal moraine is much more weathered and older; it probably correlates with glacial advances from earlier glacial cycles (see e.g. Smith et al., 2005a).

\subsubsection{Glaciation - the role of temperature}

Modelling studies in the humid parts of the Eastern Cordillera show the high sensitivity of the glacier mass balance to temperature changes (Klein et al., 1999; Kull et al., 2003, 2007; Imhof et al., 2006). Provided that moisture availability did not become a limiting factor in the past, glacial advances should therefore have coincided with temperature minima, i.e. particularly the LGM at $\sim 20-25 \mathrm{ka}$. During the Late Glacial and the general warming trend, a sudden 


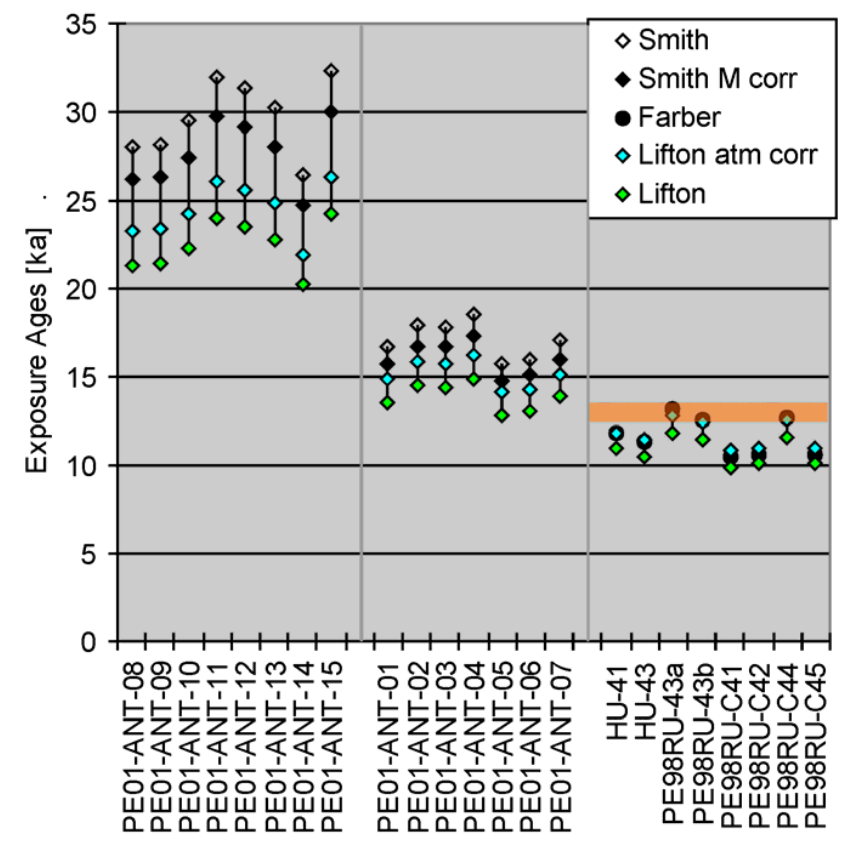

Fig. 7. Recalculated exposure ages (using Lifton et al., 2005, PR 5.87) from the Valle Antacocha (Smith et al., 2005a, b; open diamonds: uncorrected; black diamonds: geomagnetically corrected) and the "Breque" moraine (Farber et al., 2005: black circles). The orange box illustrates the ${ }^{14} \mathrm{C}$ age of the Breque moraine, a potential but controversial calibration site.

drop in temperature occurred both in Antarctica, known as Antarctic Cold Reversal (ACR, 14.5-12.9 cal ka) (Petit et al., 1999), and in the Northern Hemisphere, known as the Younger Dryas (YD, 12.9-11.6 cal ka) (NGRIP members 2004). Both high-latitude cold events were likely able to significantly affect the low-latitude temperatures (Clement et al., 2004; Chiang and Bitz, 2005) and thus to provide favourable conditions for the Late Glacial advances in the Eastern Cordilleras between $\sim 11$ and $13 \mathrm{ka}$. The earlier advances dated to $15 \mathrm{ka}$ may coincide with the Heinrich 1 event, during which very cold conditions are documented in the North Atlantic region.

Based on climate modelling, Clement et al. (2004) suggested that, in contrast to glacial forcing by high-latitude temperatures, precessional solar forcing has only a minor influence on tropical temperatures. Nevertheless, we point out that the significant Late Glacial advances dated to $\sim 11-$ $13 \mathrm{ka}$ coincide with the minimum austral summer insolation (December). Their large extent relative to the LGM advances may therefore partly be due to direct insolation forcing, i.e. reduced ablation.

\subsubsection{Glaciation - the role of precipitation}

It has previously been suggested that glacial advances in the Central Andes were synchronous with massive pre-LGM and Late Glacial wet phases on the Altiplano (Choqueyapu I and
Choqueyapu II advances, and the "Minchin" and "Tauca" phases, respectively) (e.g. Servant and Fontes, 1978; Clayton and Clapperton, 1995, 1997; Clapperton et al., 1997; Sylvestre et al., 1999). A recent study applying ${ }^{14} \mathrm{C}$ and U/Th dating techniques could, however, not corroborate the existence of the Minchin wet period (Placzek et al., 2006). Shorelines from three deep paleolakes on the Altiplano were dated to 120-98 ka (called "Ouki"), 18-14 ka ("Tauca") and 13-11 ka ("Coipasa"). Only shallow lakes existed between 98 and $18 \mathrm{ka}$. Note that these findings do not necessarily disagree with sediment-core records in the Salar de Uyuni indicating wet conditions from $\sim 25$ to $15 \mathrm{ka}$ (Baker et al., $2001 b)$. This is because the cores not only provide information about the local hydrological conditions, but also record overflow of Lake Titicaca to the north. There, several lake level proxies show high moisture availability since $25 \mathrm{ka}$ except during the dry Mid-Holocene (Baker et al., 2001a).

With regard to the glacial history, the precipitation records on the Altiplano are interpreted as follows: glaciers in the relatively wet Eastern Cordilleras are sensitive to temperature changes and therefore advanced at $\sim 20-25, \sim 15$ and $\sim 11-13 \mathrm{ka}$. Of course, very humid conditions during the Tauca and Coipasa phase provided favourable conditions for Late Glacial glacier advances. This is corroborated by high accumulation-ablation-ratios (AARs $\sim 0.8$ ) reconstructed for the respective moraines (Kull et al., 2007). On the other hand, glaciation in the dry areas farther south and west is much more sensitive to moisture availability (Kull, 1999; Kull and Grosjean, 2000; Kull et al., 2007). This is reflected by the lack of LGM moraines. Instead, massive Late Glacial glacier advances on the Altiplano and the Western Cordillera have been described and dated for example by Clapperton et al. (1997) and Clayton and Clapperton (1997).

\section{Conclusions}

We conducted ${ }^{10} \mathrm{Be}$ surface exposure dating on 28 boulders from moraines in three research areas in the Cordillera Real and the Cordillera Cochabamba. Being aware of samplespecific uncertainties, such as pre-exposure, landform surface instability, and rock surface erosion, we tentatively established a glacial chronology applying the "oldest age model". Maximum glaciation is dated to $\sim 22-25 \mathrm{ka}$, and Late Glacial advances occurred between 11 and $13 \mathrm{ka}$. Our results are in good agreement with previously published exposure age chronologies from the Eastern Cordillera in Bolivia and Peru (Farber et al., 2005; Smith et al., 2005a, b), provided that the same calculation schemes are applied. Although there is an ongoing debate as to which scaling system is more appropriate, we argue that the application of the recently published scaling system of Lifton et al. (2005) yields more accurate exposure ages than the still most widely used calculation scheme of Stone (2000). Apart from the selection of the scaling system, exposure age uncertainties are due to 
the choice of the reference production rate, i.e. the choice of the calibration sites. In the Andes, exposure ages may require corrections for persistent altitude-pressure anomalies.

Provided that our choice of the scaling system yields more accurate exposure ages, previous studies may have overestimated the real moraine ages. Our proposed glacial chronology is consistent with published radiocarbon data, lake sediment analyses, and results from glacier-climatemodelling. Glaciation in the relatively wet areas of the Andes are mainly temperature-sensitive, i.e. roughly synchronous with the global LGM and the cold reversals during the Late Glacial (YD and ACR). On the other hand, glaciation in the drier parts of the Andes is mainly precipitation-sensitive; glaciers therefore reached a maximum extent synchronous with the "Tauca" and "Coipasa" humid phase during the Late Glacial.

Overall, our study highlights (i) the limitations of exposure studies due to sample-specific uncertainties and the resultant need for a large exposure age dataset, (ii) the limitations due to systematic uncertainties and the resultant need for local calibration studies, and (iii) the huge potential of surface exposure dating for the reconstruction of the glacial and climate history in the Central Andes, and a better understanding of the forcings and mechanisms of Late Quaternary climate change in general.

Acknowledgements. We thank the Swiss National Science Foundation for funding (SNF project 21-067937.02/1), N. Lifton and M. Vuille for very detailed and helpful comments and discussions on a previous version of this manuscript, J. Smith for her detailed and constructive review, and J. Ilgner for help with calculating production rates and exposure ages. R. Zech gratefully acknowledges the support by the "Studienstiftung des deutschen Volkes e.V.".

Edited by: M. Fuchs

\section{References}

Ammann, C., Jenny, B., Kammer, K., and Messerli, B.: Late Quaternary Glacier response to humidity changes in the arid Andes of Chile (18-29 ${ }^{\circ}$ S), Palaeogeogr. Palaeocl., 172, 313-326, 2001.

Argollo, J.: Los Pie de Montes de la Cordillera Real entre los Valles de La Paz y de Tuni: Estudio Geologico, Evolution PlioCuaternaria, Tesis de Grado, Departamento de Geociencias, Facultad de Ciencias Puras y Naturales, Universidad Mayor de San Andres, La Paz, Bolivia, 100 pp., 1980.

Baker, P. A., Rigsby, C. A., Seltzer, G. O., Fritz, S. C., Lowenstein, T. K., Bacher, N. P., and Veliz, C.: The history of South American tropical precipitation for the past 25000 years, Science, 291, 640-643, 2001a.

Baker, P. A., Rigsby, C. A., Seltzer, G. O., Fritz, S. C., Lowenstein, T. K., Bacher, N. P., and Veliz, C.: Tropical climate changes at millennial and orbital timescales on the Bolivian Altiplano, Nature, 409, 698-701, 2001b.

Briner, J. P., Kaufman, D. S., Manley, W. F., Finkel, R. C., and Caffee, M. W.: Cosmogenic exposure dating of late Pleistocene moraine stabilization in Alaska, Geol. Soc. Am. Bull., 117(7), 1108-1120, 2005.

Chiang, J. and Bitz, C.: Influence of high latitude ice cover on the marine Intertropical Convergence Zone, Clim. Dynam., 25(5), 477-496, 2005.

Clapperton, C. M., Clayton, J. D., Benn, D. I., Marden, C. J., and Argollo, J.: Late Quaternary glacier advances and palaeolake highstands in the Bolivian Altiplano, Quatern. Int., 38-39, 4959, 1997.

Clayton, J. D. and Clapperton, C. M.: The last glacial cycle and paleolake synchrony in the southern Bolivian Altiplano: Cerro Azanaques case study, Bull. Inst. Fr. Etudes Andines, 24, 563$571,1995$.

Clayton, J. D. and Clapperton, C. M.: Broad Synchrony of a LateGlacial Glacier Advance and the Highstand of Palaeolake Tauca in the Bolivian Altiplano, J. Quaternary Sci., 12, 169-182, 1997.

Clement, A. C., Hall, A., and Broccoli, A. J.: The importance of precessional signals in the tropical climate, Clim. Dynam., 22(4), 327-341, 2004.

Desilets, D. and Zreda, M.: On scaling cosmogenic nuclide production rates for altitude and latitude using cosmic-ray measurements, Earth Planet. Sci. Lett., 193, 213-225, 2001.

Desilets, D. and Zreda, M.: Spatial and temporal distribution of secondary cosmic-ray nucleon intensities and applications to in situ cosmogenic dating, Earth Planet. Sci. Lett., 206, 21-42, 2003.

Desilets, D., Zreda, M., and Prabu, P.: Extended scaling factors for in situ cosmogenic nuclides: New measurements at low latitude, Earth Planet. Sci. Lett., 246, 265-276, 2006.

Dunai, T. J.: Scaling factors for production rates of in-situ produced cosmogenic nuclides: a critical reevaluation, Earth Planet. Sci. Lett., 176, 157-169, 2000.

Dunai, T. J.: Influence of secular variation of the geomagnetic field on production rates of in situ produced cosmogenic nuclides, Earth Planet. Sci. Lett., 193, 197-212, 2001.

Dunne, A., Elmore, D., and Muzikar, P.: Scaling factors for the rates of production of cosmogenic nuclides for geometric shielding and attenuation at depth on sloped surfaces, Geomorphology, 27, 3-11, 1999.

Farber, D. L., Hancock, G. S., Finkel, R. C., and Rodbell, D. T.: The age and extent of tropical alpine glaciation in the Cordillera Blanca, Peru, J. Quaternary Sci., 20(7-8), 759-776, 2005.

Fleming, K., Johnston, P., Zwartz, D., Yokoyama, Y., Lambeck, K., and Chappell, J.: Refining the eustatic sea-level curve since the Last Glacial Maximum using far- and intermediate-field sites, Earth Planet. Sci. Lett., 163(1-4), 327-342, 1998.

Gosse, J. C. and Phillips, F. M.: Terrestrial in situ cosmogenic nuclides: theory and application, Quat. Sci. Rev., 20, 1475-1560, 2001.

Guyodo, Y. and Valet, J. P.: Global changes in intensity of the Earth's magnetic field during the past 800 kyr, Nature, 399, 249252, 1999.

Harrison, S. P.: The Pleistocene glaciations of Chile, in: Quaternary Glaciations - Extent and Chronology. Part III: South America, Asia, Africa, Australasia, Antarctica, edited by: Ehlers, J. and Gibbard, P. L., Cambridge, 2004.

Heine, K.: The extent of the last glaciation in the Bolivian Andes (Cordillera Real) and paleoclimate implications, Z. Geomorph. N. F., 104, 187-202, 1996.

Heine, K.: Late Quaternary glaciations of Bolivia, in: Quaternary 
Glaciations - Extent and Chronology. Part III: South America, Asia, Africa, Australasia, Antarctica, edited by: Ehlers, J. and Gibbard, P. L., Cambridge, 2004.

Imhof, S., Kull, C., May, J.-H., Grosjean, M., and Veit, $\mathrm{H}$.: Massive cooling of $-6.5^{\circ} \mathrm{C}$ caused local last glaciation maximum (LLGM) in the east-Andean Cordillera around Cochabamba/Bolivia ( $\left.17^{\circ} \mathrm{S}\right)$, Geographica Helvetica, 61, 91106, 2006.

Ivy-Ochs, S.: The dating of rock surface using in situ produced ${ }^{10} \mathrm{Be},{ }^{26} \mathrm{Al}$ and ${ }^{36} \mathrm{Cl}$, with examples from Antarctica and the Swiss Alps, Dissertation ETH No. 11763, Zürich, 197 pp., 1996.

Jordan, T. E., Reuter, G., Leinweber, P., Alfaro, H., and Condo, A.: Pleistocene moraine sequences in different areas of glaciation in the Bolivian Andes, Zbl. Geol. Paläontol., H 1/2, 455-470, 1993.

Kaser, G.: Glacier-climate interaction at low latitudes, J. Glaciol., 47(157), 195-204, 2001.

Klein, A. G., Seltzer, G. O., and Isacks, B. L.: Modern and Last Local Glacial Maximum snowlines in the Central Andes of Peru, Bolivia and Northern Chile, Quat. Sci. Rev., 18, 63-84, 1999.

Kull, C.: Modellierung paläoklimatischer Verhältnisse basierend auf der jungpleistozänen Vergletscherung in Nordchile - Ein Fallbeispiel aus den Nordchilenische Anden, Z. Gletscherk. Glazialgeol., 35, 35-64, 1999.

Kull, C. and Grosjean, M.: Late Pleistocene climate conditions in the North Chilean Andes drawn from a Climate-Glacier Model, J. Glaciol., 46, 622-632, 2000.

Kull, C., Grosjean, M., and Veit, H.: Modeling Modern and Late Pleistocene Glacio-Climatological Conditions in the North Chilean Andes (29-30 $)$, Climatic Change, 52, 359-381, 2002.

Kull, C., Hanni, F., Grosjean, M., and Veit, H.: Evidence of an LGM cooling in NW-Argentina $\left(22^{\circ} \mathrm{S}\right)$ derived from a glacier climate model, Quatern. Int., 108(1), 3-11, 2003.

Kull, C., Imhof, S., Grosjean, M., Zech, R., and Veit, H.: Late Pleistocene glaciation in the Central Andes: Temperature versus humidity control - A case study from the eastern Bolivian Andes $\left(17^{\circ} \mathrm{S}\right)$ and regional synthesis, Global Planet. Change, doi:10.1016/j.gloplacha.2007.03.011, in press, 2007.

Lal, D.: Cosmic ray labeling of erosion surfaces: In situ nuclide production rates and erosion models, Earth Planet. Sci. Lett., 104, 429-439, 1991.

Lauer, W. and Rafiqpoor, M. D.: Die jungpleistozäne Vergletscherung im Vorland der Apolobamba-Kordillere (Bolivien), Erdkunde, 40, 125-145, 1986.

Lauer, W. and Rafiqpoor, M. D.: Zum Stand der Pleistozänforschung in der nordöstlichen Kordillere von Bolivien, Erdkunde, 43, 228-231, 1989.

Lifton, N. A., Bieber, J. W., Clem, J. M., Duldig, M. L., Evenson, P., Humble, J. E., and Pyle, R.: Addressing solar modulation and long-term uncertainties in scaling secondary cosmic rays for in situ cosmogenic nuclide applications, Earth Planet. Sci. Lett., 239(1-2), 140-161, 2005.

Mark, B. G., Seltzer, G. O., and Rodbell, D. T.: Late Quaternary glaciations of Ecuador, Peru and Bolivia. in: Quaternary Glaciations - Extent and Chronology. Part III: South America, Asia, Africa, Australasia, Antarctica, edited by: Ehlers, J. and Gibbard, P. L., Cambridge, 2004.

Markgraf, V., Baumgartner, T. R., Bradbury, J. P., Diaz, H. F., Dunbar, R. B., Luckman, B. H., Seltzer, G. O., Swetnam, T. W., and Villalba, R.: Paleoclimate reconstruction along the Pole-Equator-
Pole transect of the Americas (PEP 1), Quat. Sci. Rev., 19(1-5), 125-140, 2000.

Merrill, R. T. and McElhinny, M. W.: The Earth's Magnetic Field: Its History, Origin, and Planetary Perspective, London (Academic Press), 401 pp., 1983.

NGRIP Members: High-resolution record of Northern Hemisphere climate extending into the last interglacial period, Nature, 431, 147-151, 2004.

Ohno, M. and Hamano, Y.: Global analysis of the geomagnetic field: Time variation of the dipole moment and the geomagnetic pole in the Holocene, J. Geomag. Geoelectr., 45, 1455-1466, 1993.

Osmaston, H. A.: Should Quaternary sea-level changes be used to correct glacier ELAs, vegetation belt altitudes and sea level temperatures for inferring climate changes?, Quat. Res., 65, 244251, 2006.

Petit, J. R., Jouzel, J., Raynaud, D., Barkov, N. I., Barnola, J.-M., Basile, I., Bender, M., Chappellaz, J., Davis, M., Delaygue, G., Delmotte, M., Kotlyakov, V. M., Legrand, M., Lipenkov, V. Y., Lorius, C., Pepin, L., Ritz, C., Saltzman, E., and Stievenard, M.: Climate and atmospheric history of the past 420000 years from the Vostok ice core, Antarctica, Nature, 399, 6735, 429436, 1999.

Pigati, J. S. and Lifton, N. A.: Geomagnetic effects on timeintegrated cosmogenic nuclide production with emphasis on in situ ${ }^{14} \mathrm{C}$ and ${ }^{10} \mathrm{Be}$, Earth Planet. Sci. Lett., 226, 193-205, 2004.

Placzek, C., Quade, J., and Patchett, P. J.: Geochronology and stratigraphy of late Pleistocene lake cycles on the southern Bolivian Altiplano: Implications for causes of tropical climate change, Geological Soc. Am. Bull., 118(5), 515-532, 2006.

Putkonen, J. and O'neal, M.: Degradation of unconsolidated Quaternary landforms in the western North America, Geomorphology, 75(3-4), 408-419, 2006.

Putkonen, J. and Swanson, T.: Accuracy of cosmogenic ages for moraines, Quat. Res., 59, 255-261, 2003.

Reuter, G., Jordan, T. E., Leinweber, P., and Condo, A.: Eigenschaften, Entwicklungstendenzen und Altersunterschiede von Moränenböden in den bolivianischen Anden, Petermann. Geogr. Mitt., 139, 259-282, 1995.

Rodbell, D. T.: The timing of the last deglaciation in Cordillera Oriental, northern Peru, based on glacial geology and lake sedimentology, Geological Soc. Am. Bull., 105, 923-934, 1993.

Rodbell, D. T. and Seltzer, G. O.: Rapid ice margin fluctuations during the Younger Dryas in the Tropical Andes, Quat. Res., 54, 328-338, 2000.

Schaefer, J. M., Denton, G. H., Barrell, D. J. A., Ivy-Ochs, S., Kubik, P., Andersen, B. G., Phillips, F. M., Lowell, T. V., and Schlüchter, C.: Near-synchronous interhemispheric termination of the Last Glacial Maximum in mid-latitudes, Science, 312, 1510-1513, 2006.

Seltzer, G. O.: A lacustrine record of late Pleistocene climatic change in the subtropical Andes, Boreas, 23, 105-111, 1994.

Seltzer, G. O., Rodbell, D. T., and Abbott, M.: Andean glacial lakes and climate variability since the last glacial maximum, Bulletin de L'Institut Francais d'Etudes Andines, 24(3), 539-549, 1995.

Seltzer, G. O., Rodbell, D. T., Baker, P. A., Fritz, S. C., Tapia, P. M., Rowe, H. D., and Dunbar, R. B.: Early warming of tropical South America at the last glacial-interglacial transition, Science, 296, 1685-1686, 2002. 
Servant, M. and Fontes, J.: Les lacs quaternaires des hauts plateaux des Andes Boliviennes: Premieres interpretations paleoclimatiques, Cah. O.R.S.T.O.M., Ser. Geol., 10, 9-23, 1978.

Servant, M., Fontes, J., Argollo, J., and Saliege, J. F.: Variations du regime et de la nature des precipitations au cours des 15 derniers millenaires dans les Andes de Bolivie, Comptes Rendus de l'Academie des Sciences Paris, Serie II 292, 1209-1212, 1981.

Shanahan, T. M. and Zreda, M.: Chronology of Quaternary glaciations in East Africa, Earth Planet. Sci. Lett., 177, 23-42, 2000.

Shulmeister, J., Rodbell, D. T., Gagan, M. K., and Seltzer, G. O.: Inter-hemispheric linkages in climate change: paleo-perspectives for future climate change, Clim. Past, 2, 167-185, 2006, http://www.clim-past.net/2/167/2006/.

Smith, J. A., Finkel, R. C., Farber, D. L., Rodbell, D. T., and Seltzer, G. O.: Moraine preservation and boulder erosion in the tropical Andes: interpreting old surface exposure ages in glaciated valleys, J. Quat. Sci., 20(7-8), 735-758, 2005a.

Smith, J. A., Seltzer, G. O., Farber, D. L., Rodbell, D. T., and Finkel, R. C.: Early Local Last Glacial Maximum in the Tropical Andes, Science, 308, 678-681, 2005b.

Smith, J. A., Seltzer, G. O., Rodbell, D. T., and Klein, A. G.: Regional synthesis of last glacial maximum snowlines in the tropical Andes, South America, Quatern. Int., 138-139, 145-167, 2005c.
Solanki, S. K., Usoskin, I. G., Kromer, B., Schüssler, M., and Beer, J.: Unusual activity of the Sun during recent decades compared to the previous 11000 years, Nature, 431, 1084-1087, 2004.

Stone, J. O.: Air pressure and cosmogenic isotope production, J. Geophys. Res., 105, 23 753-23 759, 2000.

Sylvestre, F., Servant, M., Servant-Vildary, S., Causse, C., Fournier, M., and Ybert, J.-P.: Lake-Level Chronology on the Southern Bolivian Altiplano (18-23 S) during Late-Glacial Time and the Early Holocene, Quat. Res., 51, 54-66, 1999.

Vuille, M. and Ammann, C.: Regional Snowfall Patterns in the High, Arid Andes (South America), Climatic Change, 36, 413 423, 1997.

Vuille, M. and Keimig, F.: Interannual Variability of Summertime Convective Cloudiness and Precipitation in the Central Andes Derived from ISCCP-B3 Data, J. Climate, 17(17), 3334-3348, 2004.

Yang, S., Odah, H., and Shaw, J.: Variations in the geomagnetic dipole moment over the last 12000 years, Geophys. J. Int., 140, 158-162, 2000.

Zech, R., Glaser, B., Sosin, P., Kubik, P. W., and Zech, W.: Evidence for long-lasting landform surface instability on hummocky moraines in the Pamir Mountains from surface exposure dating, Earth Planet. Sci. Lett., 237, 453-461, 2005.

Zhou, J. and Lau, K.-M.: Does a monsoon climate exist over South America?, J. Climate, 11(5), 1020-1040, 1998. 